\title{
SISI LAIN PENDIDIKAN ISLAM
}

\author{
NUR HAMZAH \\ Penulis adalah Dosen IAIN Pontianak
}

\begin{abstract}
ABSTRAK
In Indonesian education system, the madrasah is one of the most important institutions. This is because of the madrasah serves as the bridge connecting the purely religious education -such as the boarding school, mosque and surau-- and modern public education such as schools. Regarding the aspect of scientific development, the madrasah develops and teaches sciences commonly taught in the public school as well as teaching religious education normally instructed in the boarding school. In the domain of teaching method and system, the madrasah education is also an innovation and development of the methods implemented in the boarding school. Therefore, the madrasah an education institution that teaches both general and religious-based sciences. However, some madrasahs are facing complicated issues such as the problem of human resources, facilities, sources of funds, incompetent management, government policies that are not in favor of the madrasah, and the graduates that are not prepared to compete in the global era.
\end{abstract}

Keywords: Madrasah, problems

\section{PENDAHULUAN}

Membincang tentang pendidikan Indonesia, tidak bisa kita melepaskannya dengan madrasah sebagai lembaga pendidikan Islam. Banyak konstribusi yang telah diberikan madrasah sebagai penyelenggara pendidikan di negeri ini. Ukuran konstribusi itu salah satunya adalah bahwa madrasah ikut memperluas akses kesempatan mengenyam pendidikan bagi anak usia sekolah. Hal itu sangat memungkinkan karena keberadaan madrasah yang sebagian besar ada di pelosok, pedalaman atau pinggiran daerah.

Selain sebagai penyambung akses kesempatan memperoleh pendidikan, madrasah juga menjadi wadah untuk mentransformasikan pengetahuan dan nilai agama. Jika di sekolah umum pelajaran agama hanya mendapat porsi waktu 2 jam pelajaran, maka hal ini dirasakan sangat tidak memadai. Agama yang menurut hampir semua orang adalah pilar tak tergantikan dalam pembentukkan karakter menjadi sangat penting untuk ditransformnasikan melalui lembaga pendidikan seperti sekolah. Pada madrasah, mata pelajaran agama lebih banyak porsi waktunya. Pelajaran agama selanjutnya di pecah menjadi mata pelajaran Al-quran Hadist, Fiqh, Aqidah Akhlak dan Sejarah Islam. Terlebih lagi jika di madrasah aliyah jurusan agama, mata pelajaran agama menjadi lebih dispesfikkan seperti ada mata pelajaran Tarikh Tasyri', Ushul Fiqh, Ilmu Kalam dan lain sebagainya. Melalui lembaga pendidikan madrasah inilah diharapkan terjadi pewarisan keilmuan keagamaan Islam.

Pada aspek yang lain, pendidikan yang diselenggarakan oleh madrasah juga memberikan keterampilan tambahan kepada 
siswanya seperti Tilawah (membaca indah Al-Quran), Khattil Quran (menulis indah Al-Quran), membaca "kitab kuning", termasuk kadang keterampilan dasar hidup lainnya (Life skill). Keterampilan keagamaan ini biasanya di lombakan (musabaqah) antar madrasah hingga tingkat nasional. Tambahan keterampilan selain ilmu pengetahuan formal tentunya akan memperkaya pengetahuan, skill dan pengalaman siswa agar lebih siap saat kembali terjun ke masyarakat.

Untuk konteks Indonesia, madrasah dengan peran signifikan dan urgennya tersebut pendirian madrasah tidak hanya di inisiasi oleh pemerintah tetapi juga oleh perorangan atau sekelompok orang. Bahkan di negeri ini, bahwa lembaga pendidikan madrasah yang dikelola oleh yayasan swasta jumlahnya lebih banyak ketimbang madrasah yang dibawah naungan pemerintah (kementerian agama). Hal ini menunjukkan bahwa kebutuhan dan kepedulian terhadap madrasah sangat urgen. Ditengah lembaga pendidikan umum misalkan, madrasah masih mendapat eksistensi dan apresiasi bagi masyarakat dilokusnya. Masyarakat punya harapan bahwa madrasah akan memberikan tidak hanya sekedar pengetahuan yang dibutuhkan untuk bertahan dan bersaing hidup, tetapi juga dapat membekali anak mereka dengan suatu yang dapat menyelematkan kehidupan saat diakhirat kelak. Oleh sebab itu maka, madrasah di Indonesia ini akan tetap dapat survive juga eksist manakala masih banyak orang yang berpikir sedemikian.

Tetapi perkara membuat madrasah tetap survive dan eksist bukanlah perkara mudah dan hanya cukup sedemikian. Di antara madrasah, terdapat lembaga pendidikan lain yang dimana ia niscaya dapat bersaing atau paling tidak setara. Jika madrasah tidak dapat menunjukkan kelebihannya maka ia secara perlahan akan ditinggalkan. Pesona madrasah sebagai lembaga pendidikan yang memberikan nilai lebih akan menjadi pudar karena ia tidak dikelola secara baik atau menghasilkan output berkualitas. Demikian faktanya bahwa diantara sejumlah madrasah yang berdiri, sebgian diantaranya dalam kondisi memprihatinkan bahkan hingga tutup. Ini maknanya bahwa madrasah sebagai sebuah lembaga pendidikan didirikan tidak hanya bisa dengan modal niat dan keingginan. Komitmen mendirikan madrasah niscaya berbarengan dengan ikhtiar keras juga cerdas yang sistematis, berkesinambungan dan terprogram.

Di Kalimantan Barat, walaupun tidak sebanyak di propinsi Jawa Timur, Jawa Barat, Jawa Tengah dan Kalimantan Selatan, tetapi jumlah madrasah di daerah ini cukup signifikan. Ini menunjukkan bahwa ghirah mendirikan madrasah sebagai pusat pendidikan Islam juga tinggi. Adapun sebarannya, yang paling banyak adalah di Kabupaten Kubu Raya, Kabupaten Mempawah, Kabupaten Sambas dan Kabupaten Sintang.

Pada satu sisi hal ini tentu merupakan kondisi yang menggembirakan. Namun pada sisi yang berbeda keberadaan madrasah merupakan tantangan, sebab dibalik kerja mendirikan madrasah, terdapat kerja lain yang lebih riil dan berat yakni bagaimana menjalankan proses pembelajaran yang kontinyu, kondusif, edukatif, sistematis dan lain sebagainya.

Jika melihat lebih dalam kondisi riil madrasah, sebagian madrasah eksist dan dapat bersaing dengan lembaga pendidikan formal lain. Sebutlah misalnya MAN 1 dan 2 Pontianak, MAN Model Singkawang, MAS Darussalam Sengkubang dan lain sebagainya (walaupun harus dibuktikan lebih lanjut dengan penelitian). Sebagian lagi, kondisi madrasah memprihatinkan. Sebutlah diantaranya berdasarkan hasil penelitian penulis yakni Madrasah Ibtidaiyah Darussuadah di Desa Tebang Kacang. Madrasah ini berdiri tahun 2005, tepatnya dilokasi eks pengungsian kerusuhan sosial Sambas. Dari hasil 
observasi, madrasah ini hanya memiliki 3 ruang belajar sementara rombongan belajar ada 6. Sarana belajar seperti bangku dan meja tidak layak sebagai meja belajar karena meja yang digunakan adalah meja dan kursi panjang yang muat untuk 6-8 orang. Ruang belajar hanya berukuran $5 \times 5$ meter sementara ukuran ideal adalah $8 \times 8$ M2. Belum lagi fasilitas lain, bahwa madrasah ini tidak memiliki kantor dan ruang guru. Mensiasati hal ini kepala sekolah melakukan pengadministrasian pendidikan di rumahnya. Guru juga berkumpul di rumahnya saat selesai mengajar. Madrasah ini juga tidak memiliki koleksi perpustakaan untuk sumber belajar anak, tidak memiliki sarana media pembelajaran, tidak memiliki toilet dan lain sebagainya. Belum lagi tentang tenaga pendidik. Tidak ada satupun baik kepala sekolah maupun guru yang lulusan strata satu. Paling tinggi adalah ada diantara guru yang sedang dalam penyelesaian $\mathrm{S} 1$, sementara yang lain tamatan SMA sederajat atau pesantren. Kondisi yang ada pada MI Darussuada ini tentu sangat miris yang menggambarkan sisi lain dari madrasah, dan dari hasil penelitian penulis, kondisi yang sama juga berlaku pada beberapa madrasah lain mulai dari tingkat Raudhatul Atfal, Ibtidaiyah, Tsanawiyah dan Aliyah.

\section{PROBLEMATIKA PENDIDIKAN DI MADRASAH}

Dalam peta pendidikan Indonesia, madrasah adalah salah satu lembaga pendidikan terpenting. Dianggap terpenting karena madrasah merupakan jembatan penghubung antara pendidikan agama murni seperti pesantren, masjid dan surau dengan pendidikan umum modern seperti sekolah. ${ }^{1}$ Pada aspek pengembangan keilmuan, madrasah mengembangkan dan mengajarkan ilmu umum yang di sekolah

1 Malik Fajar, Madrasah dan Tantangan Modernitas, Bandung, Mizan, 1998 h. 23 sekaligus mengajarkan ilmu agama sebagaimana di pesantren. Dalam ranah metode dan sistem pengajaran juga demikian bahwa metode pelaksanaan pendidikan madrasah adalah inovasi dan pengembangan dari metode yang dilaksanakan di pesantren. Termasuk dalam hal ini adalah bahwa madrasah adalah lembaga pendidikan yang mewariskan keilmuan umum dan agama.

Tetapi fakta urgensitas di atas tidak sebagaimana nyatanya. Kondisi riil madrasah untuk mewujudkan sigifikansi kehadirannya dihadapkan pada fakta-fakta masalah. Di antara masalah yang dirasakan oleh madrasah secara umum terutama yang ada di Kalimantan Barat adalah:

1. Kondisi sarana dan pra-sarana pendukung PBM yang minim. Banyak madrasah yang didirikan awalnya tidak memiliki gedung sendiri melainkan menumpang. Kalau pun ada gedung yang mereka miliki kondisinya sangat memprihatinkan. Ruang kelas yang ada tidak sebagaimana yang telah terstandarkan oleh lembaga berwenang seperti BAN. Belum lagi jika melongok kondisi sarana lain misalnya kelengkapan referensi perpustakaan, peralatan laboratorium, alat peraga mata pelajaran dan lain sebagainya;

2. Keterbatasan sumber daya manusia. Sumber daya manusia ini adalah tenaga guru dan tenaga kependidikan. Masih banyak madrasah yang tenaga gurunya tamatan SMA sederajat atau pesantren yang seharusnya adalah minimal starata satu (S1). Belum lagi jika berbicara tentang kesesuaian latar belakang pendidikan dengan mata pelajaran yang diajar. Karena keterbatasan ini maka banyak guru yang mengajar tidak sesuai dengan bidangnya;

3. Keterbatasan sumber pendanaan. Sudah menjadi fakta bahwa jumlah madrasah di Indonesia ini termasuk Kalimantan Barat sebagian besar dikelola oleh pihak swasta wa bil khusus yayasan. Yayasan 
terkadang hampir tidak memiliki sumber pembiayaan lain kecuali dari bantuan pemerintah dan dari siswa. Jika hanya mengandalkan dari dua sumber ini maka hampir dipastikan madrasah akan kekurangan dana operasional. Karena kekurangan sumber pembiayaan maka program pengembangan kependidikan menjadi tersendat. Biaya lebih banyak dialokasi pada unsur belanja pegawai. Keterbatasan sumber pendanaan ini juga beriringan dengan keterbatasan inovasi dan kreativitas yayasan untuk mengelola sumber dana. Sumber pendaan terutama dari pihak ke tiga atau mandiri seyogyanya sangat bisa dimaksimalkan untuk mendukung operasional madrasah jika pihak yayasan jeli dalam menawarkan dan memenej potensi tersebut. Di beberapa madrasah penulis jumpai letak lokasi persis ditengah perkebunan sawit yang dikelola pihak swasta, tetapi hampir tidak pernah perusahaan tersebut mengucurkan CSR nya ke lembaga madrasah. Hal tersebut tidak bisa juga disalahkan kepada pihak perusahaan karena madrasah dalam hal ini tidak pernah melakukan komunikasi dan membuat tawaran (proposal) desain pengembangan lembaga yang menghendaki partisipasi pihak ke-3. Demikian pula di beberapa madrasah penulis melihat sumber daya alam yang dapat dikelola untuk mengembangkan dan menambah income madrasah dibiarkan begitu saja. Beberapa madrasah memiliki lahan yang sangat luas hingga belasan hektar, tetapi lahan luas tersebut dibiarkan kosong dan menjadi hutan begitu saja. Demikian pula ada madrasah yang lokasinya dekat dengan suangai yang di daerah tersebut sentra budidaya ikan tambak. Tetapi lagi-lagi pihak yayasan tidak terinspirasi untuk membuat hal serupa. Paling maksimal yang biasa pihak yayasan untuk mengumpulkan dana adalah membuat proposal pengembangan bangunan untuk selanjutnya diajukan ke pemerintah kabupaten atau perorangan donatur.

4. Kebijakan pemerintah yang masih setengah hati. Sebagaimana diketahui bahwa baru beberapa dekade belakangan saja madrasah statusnya disamakan. Disamakan artinya statusnya sama dengan sekolah, output madrasah sama dengan output sekolah. Tetapi itu saja sebenarnya tidak cukup, jika dilihat kebijakan penganggaran maka nampak ketimpangannya. Termasuk dalam hal ini adalah kebijakan pengangkatan guru, kebijakan tata kelola dan lain sebagainya.

5. Sebagian besar madrasah di Indonesia dikelola oleh stake holder yang tak berkompeten. Stake holder tersebut misalnya ketua yayasan, kepala sekolah, kepala TU termasuk komite. Ketua yayasan kadang yang diangkat adalah orang yang memiliki lembaga tersebut atau orang yang dituakan tanpa skill dan konsep pendidikan. Kepala sekolah juga kadang demikian, adalah orang yang diangkat oleh yayasan yang dianggap dapat bekerjasama dengan yayasan, oleh sebab itu mengabaikan kemampuan leader ship, managemen dan pengembangan kelembagaan pendidikan. Yang lebih miris lagi adalah bahwa stuktur yayasan dan madrasah adalah masih satu keluarga. Kondisi ini tentu saja sangat tidak sehat bagi perkembangan lembaga.

6. Khusus untuk madrasah yang masih belum terakreditasi atau terkareditasi tapi TT atau $\mathrm{C}$, hasil penelusuran penulis bahwa pengelola madrasah tidak mengerti akan standar pengelolaan sebagaimana yang di tetapkan oleh Badan Akreditasi. Pemahaman mereka terhadap standar minimal pengelolaan satu lembaga pendidikan sangat lemah, oleh karenanya penyelenggaraan pendidikan terkesan seadanya dan sebisanya saja, pada hal akreditasi 
merupukan standar minimal yang harus dipenuhi satu lembaga pendidikan untuk menunjukkan apakah penyelenggaraan pendidikan yang dilakukan saudah berkualitas atau belum.

7. Problem berikutnya adalah bahwa beberapa madrasah tidak memiliki blue print (cetak biru) pengembangan kelembagaan. Apa yang dilaksanakan oleh madrasah hanyalah menjalankan apa yang telah ada sebelumnya, hal ini disebabkan yayasan atau madrasah tidak memiliki rencana kerja baik jangka pendek, menengah atau jangka panjang. Wal hasil progres madrasah sebagai satu lembaga jalan ditempat, sementara pada wilayah yang berbeda lembaga pendidikan lain telah jauh progres dan pengembangan lembaga. Jika hal ini terjadi maka tidak mengherankan beberapa madrasah hampir tutup karena minim siswa yang masuk atau sekolah disana. Orang tua lebih memilih dan percaya pada sekolah yang lebih maju baik dari sarana, kurikulum dan hal lainnya.

8. Masalah berikutnya adalah kesiapan madrasah dalam menghadapi tuntutan globalisasi. Jika mau jujur termasuk output madrasah, masih lemah dalam adaptasinya terhadap tuntutan globalisasi. Globalisasi menghendaki lulusan yang siap di dunia kerja. Yang paling dapat diukur adalah kemampuan lulusan madrasah dapat bersaing memasuki jenjang pendidikan berikutnya baik level pendidikan menengah maupun pendidikan tinggi.

\section{PENUTUP}

Melihat sekilas didentfikasi problematika dan kelemahan madrasah tersebut, dalam rangka tetap dapat survive dan eksistens, niscaya madrasah melakukan beragam ikhtiar percepatan pengembangan lembaga. Termasuk dalam hal ini adalah upaya pemerintah selaku pemangku tertinggi kebijakan pendidikan di negara.
Berikut beberapa hal yang dapat penulis sarankan untuk percepatan pengembangan madrasah:

1. Pihak pemerintah dalam hal ini baik Kementerian Agama maupun Pemerintah Daerah dan legislator harus duduk satu meja mendiskusikan konsep model pengembangan madrasah. Tugas, wewenang dan tanggung jawab pengembangan madrasah bukan hanya menjadi milik Kementerian Keagamaan melainkan juga pemerintah daerah karena yang menjadi siswa adalah anak kabupaten/kota daerah tersebut;

2. Pihak madrasah jika menghendaki pengembangan lembaga, dapat meminta bantuan perguruan tinggi sebagai lembaga pendamping sebagai tenaga konsultan atau tim ahli;

3. Dalam hal pengembangan lembaga, pihak yayasan dan madrasah dapat mengadopsi cetak biru pengembangan madrasah lain yang telah atau lebih maju.

4. Perguruan tinggi khususnya perguruan tinggi Islam semisal IAIN niscaya menjadikan madrasah tertinggal sebagai madrasah yang menjadi prioritas untuk mendapat program dampingan;

Beberapa usulan saran tersebut tentunya masih prematur, untuk lebih implementatif tentunya bagi penggiat pendidikan dan stake holder terkait dapat menindaklanjutinya dengan diskusi dan pertemuan intens.

Wallahu'alam bi'alsawab.

\section{REFERENSI}

Malik Fajar, Madrasah dan Tantangan Modernitas, Bandung, Mizan, 1998

HS, Mastuki, Asal Usul Madrasah, Artikel dari data internet dalam www. Bagais.co.id

Muhaimin, Pengembangan Kurikulum Pendidikan Agama Islam, PT. Raja Grafindo

Persada, Jakarta, 2006. 
Hasbullah, Sejarah Pendidikan Islam di Indonesia: Lintasan Sejarah Pertumbuhan dan Perkembangan, Jakarta: PT Raja Grafindo Persada, 2001

Abdul Rchman Shaleh, Madrasah dan Pendidikan Anak Bangsa: Visi, Misi dan Aksi, Jakarta: PT RajaGrafindo Persada, 2006

Maskuri Badillah, Pesantren Dalam Konteks Pendidikan Nasional dan Pengembangan Masyarakat, (dalam Pendidikan untuk masyarakat Indonesia baru), Ikhwanuddin dan Dodo Murtadlo (editor), Jakarta, PT Grasindo, 2002

Harun Rasyid, Metode Penelitian Kualitatif Bidang Sosial dan Agama, Pontianak: STAIN Press, 2000

Suharsimi Arikunto, Prosedur Penelitian Suatu Pendekatan Praktek, Jakarta: PT Rineka Cipta, 21002 